\title{
Effect of cementation on the mechanical behavior of a nanoceramic resin
}

\section{(Efeito da cimentação no comportamento mecânico de uma resina nanocerâmica)}

\author{
A.D. Nogueiral, P. H. Corazzal ${ }^{1}$ O. E. Pecho ${ }^{1}$, M. M. Perez ${ }^{2}$, M. Borba ${ }^{1 *}$ \\ ${ }^{1}$ University of Passo Fundo, Dental School, Graduate Program in Dentistry, BR286, 99052-900, \\ Passo Fundo, RS, Brazil \\ ${ }^{2}$ University of Granada, Faculty of Science, Department of Optics, Granada, Spain
}

\begin{abstract}
Conventional flexural strength tests of restorative materials neglect the effect of essential variables that can affect their mechanical behavior. The purpose of this study was to evaluate the effect of cementation on the mechanical behavior of a nanoceramic resin. A nanoceramic resin (LU) and a leucite-reinforced glass-ceramic (IE) were evaluated. Non-cemented specimens of the materials were produced and subjected to biaxial flexural strength test $\left(\sigma_{\mathrm{f}}, \mathrm{n}=30\right)$. Cemented specimens were constituted of the restorative material bonded with resin cement onto a dentin analog substrate. Cemented specimens were subjected to the monotonic compressive load test $\left(\mathrm{L}_{\mathrm{f}}, \mathrm{n}=20\right)$. Vickers microhardness $(\mathrm{HV})$ and translucency parameter $(\mathrm{TP})$ of the materials were characterized. Data were analyzed using t-test $\left(\sigma_{\mathrm{f}}\right.$ and TP), Mann-Whitney test $\left(\mathrm{L}_{\mathrm{f}}\right.$ and $\left.\mathrm{HV}\right)$, and Weibull analysis $\left(\sigma_{\mathrm{f}}\right.$ and $\left.\mathrm{L}_{\mathrm{f}}, \alpha=0.05\right)$. Non-cemented LU showed higher $\sigma_{\mathrm{f}}$ and Weibull modulus $(\mathrm{m})$ than IE. When cemented to the substrate, LU showed higher $\mathrm{L}_{\mathrm{f}}$ than IE; however, the m-value was similar among groups. LU showed lower HV than IE and higher TP values. Cementation influenced the mechanical behavior and failure mode of the nanoceramic resin.
\end{abstract}

Keywords: ceramics, dental prosthesis, mechanics.

Resumo

Os testes convencionais de resistência à flexão de materiais restauradores negligenciam o efeito de variáveis essenciais que podem afetar seu comportamento mecânico. O objetivo deste estudo foi avaliar o efeito da cimentação no comportamento mecânico de uma resina nanocerâmica. Foram avaliadas uma resina nanocerâmica $(L U)$ e uma vitrocerâmica reforçada por leucita (IE). Foram produzidos corpos de prova $(C P)$ não cimentados dos materiais e submetidos ao teste de resistência à flexão biaxial $\left(\sigma_{f}, n=30\right)$. CPs cimentados foram constituídos pelo material restaurador cimentado adesivamente a um substrato análogo à dentina. Os CPs cimentados foram submetidos ao teste de carga compressiva monotônica $\left(L_{f}, n=20\right)$. A microdureza Vickers $(H V)$ e o parâmetro de translucidez (TP) dos materiais foram caracterizados. Os dados foram analisados pelo teste $t\left(\sigma_{f}\right.$ e TP), teste de Mann-Whitney $\left(L_{f}\right.$ e $\left.H V\right)$ e análise de Weibull $\left(\sigma_{f}\right.$ e $\left.L_{f}, \alpha=0,05\right)$. A LU não cimentada apresentou $\sigma_{f}$ e módulo de Weibull $(m)$ superiores a IE. Quando cimentada ao substrato, a LU apresentou maior $L_{f}$ que a IE; no entanto, o valor de $m$ foi semelhante entre os grupos. A $L U$ apresentou menor HV que a IE e maiores valores de TP. Concluiu-se que a cimentação influenciou o comportamento mecânico e modo de falha da resina nanocerâmica.

Palavras-chave: cerâmicas, prótese dentária, propriedade mecânica.

\section{INTRODUCTION}

Computer-aided design and computer-aided manufacturing $(\mathrm{CAD} / \mathrm{CAM})$ is a modern manufacturing technique used in Dentistry to produce indirect esthetic restorations [1]. CAD/CAM restorations can be manufactured using both composite resins or ceramics due to the improvement of their mechanical $[2,3]$ and optical properties [1, 4]. Ceramics show biocompatibility, color stability, stiffness, and are brittle [1]. On the other hand, composite resins are more resilient and can be easily polished

*marciaborba@upf.br

Dhttps://orcid.org/0000-0001-7587-9839 and repaired. However, they can change color over time due to their organic matrix content [5]. Thus, these two types of restorative materials have advantages and disadvantages.

Novel materials called "hybrid" or "high-performance polymers" were introduced, aiming to combine the properties of ceramics and polymers $[1,6]$. Most of these prepolymerized materials are composed of a resin matrix with high inorganic filler content. As they are high-temperaturepressure polymerized in the manufacturing process, there is greater control of the degree of conversion of the polymer matrix, improving their mechanical and optical properties $[4,6]$. This greater incorporation of filler increases the flexural strength, modulus of elasticity, and hardness while decreasing the polymerization shrinkage, coefficient of 
thermal expansion, coefficient of absorption, and solubility of the material [6]. There are several studies characterizing these $\mathrm{CAD} / \mathrm{CAM}$ pre-polymerized composite materials [1, 4-8]. However, in vitro findings obtained with traditional flexural strength tests could differ from the clinical behavior due to the absence of essential variables, such as the presence of a supporting substrate and the quality of the bond between the materials [9-13]. Clinically, indirect restorations are cemented on a substrate (dentin or enamel) using a luting agent. Thus, the presence of a multilayer structure composed of materials with different mechanical and elastic properties affect the stress distribution induced by the masticatory load. The mismatch between the elastic modulus of the different layers can induce a higher concentration of tensile stresses at the interface, resulting in clinical failures $[9,13]$. Moreover, the cementation interface between materials is not perfect, and the presence of flaws in this region could also be a problem [9].

It is known that cementing all-ceramic restorations with resin cements improve their clinical performance [14, 15]. The thickness and elastic modulus of the resin cement layer affect the mechanical behavior of the multilayer structures [16-18]. Moreover, the resin cement interacts directly with the surface defect population of the restorative material, and the resin-strengthening mechanisms are dependent upon the creation of a resin-ceramic hybrid layer $[18,19]$. For indirect resin composite restorations, a strengthening effect related to the adhesive cementation to the substrate is also expected. Similarities in the chemical composition, mechanical and physical properties between the resin-based restoration and cement would also favor the structure's mechanical behavior $[12,13]$. The material evaluated in this study is a CAD/CAM nanoceramic resin composed of inorganic fillers (zirconia-silica nanofillers, $80 \mathrm{wt} \%)$ and a highly cross-linked polymer containing predominantly UDMA (urethane dimethacrylate, 20 $\mathrm{wt} \%)[6,8]$. This material is indicated for inlays, onlays, and veneers [8]. Total crowns were removed from the indications because of the occurrence of clinical debonding $[6,8]$. This fact justifies the importance of evaluating this material cemented on a substrate, following a multilayer configuration, similar to clinical conditions. Therefore, the objective of the present study is to investigate the effect of cementation on the mechanical behavior of a nanoceramic resin. The hypothesis tested is that cemented specimens show different mechanical behavior and failure modes than non-cemented specimens. A leucite-reinforced glassceramic was used as a control group. The microhardness and translucency of the materials were also characterized.

\section{MATERIALS AND METHODS}

A nanoceramic resin (LU - Lava Ultimate, 3M Dental Care, St. Paul, USA) and a leucite-reinforced glass-ceramic control group (IE - IPS Empress CAD, Ivoclar Vivadent, AG, Liechtenstein) were evaluated (Table I). Restorative materials were mechanically evaluated non-cemented (biaxial flexural strength test) and cemented over a dentin analog substrate (monotonic compressive load test).

Biaxial flexural strength test: non-cemented specimens tested in biaxial flexural strength were constituted by discs with $1 \mathrm{~mm}$ thickness and $12 \mathrm{~mm}$ diameter. LU and IE CAD/ CAM blocks (shade A2, HT - high translucency) were ground into a cylindrical shape (12 $\mathrm{mm}$ in diameter) using a diamond stone (TN 634709, Tyrolit, Brazil) in a grinding machine (CA51H, Ferdimat, Brazil). Discs ( $n=30,1.04$ $\mathrm{mm}$ in thickness) were obtained from the cylinders of each material, using a metallographic cutter (Minitron, Struers, Denmark) and a diamond disc under water cooling. Discs were polished with silicon carbide papers (\#600, \#800, $\# 1000$, and \#1200 grit size) under constant water irrigation to a final thickness of $1.00 \mathrm{~mm}$. The biaxial flexural strength test was performed according to ISO 6872 standard [20]. Each specimen was positioned on the top of three spheres (2.5 $\mathrm{mm}$ in diameter) placed at $120^{\circ}$ in a metallic base $(10$ $\mathrm{mm}$ in diameter). A gradual compressive force was applied at $0.5 \mathrm{~mm} / \mathrm{min}$ cross-head speed by a $1 \mathrm{~mm}$ diameter flat piston until specimen fracture using a universal testing machine (20-10, Instron, Brazil). Specimens were immersed in water at $37{ }^{\circ} \mathrm{C}$ during the test. A polyester strip was placed between the specimen and the piston to provide a uniform stress distribution. The fracture load $(\mathrm{P})$ was recorded, and biaxial flexural strength $\left(\sigma_{\mathrm{f}}\right.$ in $\left.\mathrm{MPa}\right)$ was calculated by [20]:

$$
\begin{aligned}
& \sigma_{\mathrm{f}}=-0 \cdot 2387 \cdot P \cdot(\mathrm{X}-\mathrm{Y}) / \mathrm{b}^{2} \\
& \mathrm{X}=(1+v) \cdot \ln \left(\mathrm{r}_{2} / \mathrm{r}_{3}\right)^{2}+[(1-v) / 2] \cdot\left(\mathrm{r}_{2} / \mathrm{r}_{3}\right)^{2} \\
& \mathrm{Y}=(1+v) \cdot\left[1+\ln \left(\mathrm{r}_{1} / \mathrm{r}_{3}\right)^{2}\right]+(1-v) \cdot\left(\mathrm{r}_{1} / \mathrm{r}_{3}\right)^{2}
\end{aligned}
$$

\begin{tabular}{|c|c|c|c|c|}
\hline Code & Material & Batch & Manufacturer & Composition $^{\#}$ \\
\hline $\mathrm{LU}$ & Lava Ultimate & N807178 & $\begin{array}{l}\text { 3M Dental Care } \\
\text { (St. Paul, USA) }\end{array}$ & $\begin{array}{l}\text { Organic matrix: UDMA (20 wt } \%) \text {; filler particles ( } 80 \\
\text { wt } \%) \text { : silica }(20 \mathrm{~nm}) \text {, zirconia }(4 \text { to } 11 \mathrm{~nm}) \text {, agglomerated } \\
\text { zirconia-silica }(0.6 \text { to } 10 \mu \mathrm{m})\end{array}$ \\
\hline IE & $\begin{array}{l}\text { IPS Empress } \\
\text { CAD }\end{array}$ & V28703 & $\begin{array}{l}\text { Ivoclar Vivadent } \\
\text { (AG, Liechtenstein) }\end{array}$ & 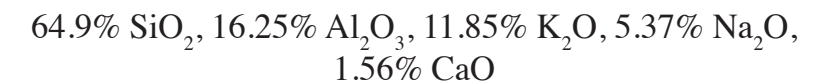 \\
\hline
\end{tabular}

Table I - Description of the materials used in the present study. [Tabela I - Descrição dos materiais utilizados no presente estudo.] 
where $\mathrm{P}$ is the fracture load $(\mathrm{N}), v$ is the Poisson's ratio, $\mathrm{r}_{1}$ is the radius of the support circle $(\mathrm{mm}), \mathrm{r}_{2}$ is the radius of the loading piston $(\mathrm{mm}), \mathrm{r}_{3}$ is the radius of the specimen $(\mathrm{mm})$, and $b$ is the thickness of the specimen (mm). The Poisson's ratio values used for the calculations were $v=0.47$ for $\mathrm{LU}$, and $v=0.173$ for IE [21].

Monotonic compressive load test: cemented specimens for the compressive load test were constituted by the restorative material bonded with resin cement to a dentin analog substrate. LU and IE CAD/CAM blocks (shade A2, HT - high translucency) were cut into slices of 1.5 $\mathrm{mm}$ thickness $(10 \times 12 \mathrm{~mm})$ using a metallographic cutter and a diamond disc under water cooling. Specimens were polished with silicon carbide papers (\#600, \#800, \#1000, and \#1200 grit size) under constant water irrigation $(n=20)$. A fiber-reinforced epoxy resin dentin analog material (NEMA G10, Int. Paper, USA) was used as a supporting substrate $[9,10]$. G10 was cut into $4 \mathrm{~mm}$ thick slices using a diamond disc under water cooling. G10 substrates were stored in distilled water for 7 days to allow hygroscopic expansion prior to cementation. The restorative materials were cemented onto the G10 substrate according to the protocol recommended by each manufacturer. The cementation surface of LU was sandblasted (Microjato, Bio-Art, Brazil) with $45 \mu \mathrm{m}$ aluminum oxide particles and a pressure of 30 psi. The cementation surfaces of IE and G10 were etched with $10 \%$ hydrofluoric acid for $60 \mathrm{~s}$, rinsed with water for 30 $\mathrm{s}$, and air-dried for $30 \mathrm{~s}$. The adhesive system (Single Bond Universal, 3M Dental Care, USA) was actively applied (with rubbing motion) for $20 \mathrm{~s}$ to the surfaces, and air-dried for $5 \mathrm{~s}$. A dual-cure resin cement (RelyX Ultimate, 3M Dental Care, USA) was mixed with a spatula for $30 \mathrm{~s}$ and applied on the treated surfaces of LU and IE, which were placed onto the substrates. A cementation device was used to apply a $750 \mathrm{~g}$ load for 3 min to the multilayered specimen in order to obtain a uniform cement layer. Cement excess was removed, and the specimen was photoactivated for $20 \mathrm{~s}$ from each side (Radii-cal, SDI, Bayswater, Australia; $1200 \mathrm{~mW} / \mathrm{cm}^{2}$ ) and from the top (total activation time of $60 \mathrm{~s}$ ). The specimens were stored in $37{ }^{\circ} \mathrm{C}$ distilled water for $48 \mathrm{~h}$ before the mechanical tests. A compressive load was applied to the center of the cemented-specimens by a $3 \mathrm{~mm}$ diameter flat ceramic piston (lithium-disilicate glass-ceramic). The test was performed in distilled water at $37{ }^{\circ} \mathrm{C}$ using a universal testing machine (20-10, Instron) with a crosshead speed of $0.5 \mathrm{~mm} / \mathrm{min}$. A polyester strip was placed between the specimen and the piston to provide a uniform stress distribution. An amplified microphone, connected to the universal testing machine and to a computer, was used to detect and record the sound of the first crack (Audacity Sound Editor, Free Software Foundation); at that moment, the test was interrupted, and the fracture load $\left(\mathrm{L}_{\mathrm{f}}\right.$ in $\mathrm{N}$ ) recorded. Specimens were analyzed using transillumination with blue light after the mechanical test in order to identify the initial crack and failure modes.
Failures were classified as follows: radial crack, when the crack was located on the lower surface of the restorative material, at the intaglio surface; cone crack, a cone-shaped crack located on the surface of the restorative material in contact with the piston; and combined, with the presence of both cracks types (cone+radial crack) [9-12].

Microhardness: fragments of the specimens $(n=5)$ from the biaxial flexural strength test were randomly selected for the microhardness test. A microhardness tester (HMV-G20, Shimadzu, Japan) and a Vickers indenter were used to apply a $100 \mathrm{kgf}$ load (P) for 15 $\mathrm{s}$ dwell time to the surface of both materials [22]. Six indentations were performed in each specimen, and the average was used in the statistical analysis. The Vickers microhardness (HV) was calculated according to [23]:

$$
\mathrm{HV}=1.854 . \mathrm{P} / \mathrm{d}^{2}
$$

where $\mathrm{P}$ is the load in $\mathrm{kgf}$, and $\mathrm{d}$ is the arithmetic mean between the two diagonals $\left(\mathrm{d}_{1}\right.$ and $\mathrm{d}_{2}$, in $\mathrm{mm}$ ) of the indentation.

Translucency parameter: to evaluate the translucency of the materials, LU and IE CAD/CAM blocks (shade A2, HT - high translucency) were cut into slices of $1.5 \mathrm{~mm}$ thickness (10x12 mm) using a metallographic cutter and a diamond disc under water cooling. Specimens were polished with silicon carbide papers (\#600, \#800, \#1000, and \#1200 grit size) under constant water irrigation. One surface of the specimen was further polished with $1 \mu \mathrm{m}$ alumina paste using a polishing machine (DP-9a, Panambra/Struers, Brazil; $n=5$ ). The relative spectral reflectance (between 380 and $780 \mathrm{~nm}$ at $2 \mathrm{~nm}$ interval) was measured (x3) against white ( $\mathrm{L}^{*}=94.70$, $\mathrm{a}^{*}=0.06$, and $\left.\mathrm{b}^{*}=3.85\right)$ and black $\left(\mathrm{L}^{*}=22.74, \mathrm{a}^{*}=-0.38\right.$, and $\left.\mathrm{b}^{*}=-1.67\right)$ backgrounds for each specimen using a noncontact spectroradiometer (SpectraScan PR-670, Photo Research, USA), a fiber-coupled Xe-arc light source (Oriol Research, Newport Co., USA), and a spectrally calibrated reflectance standard (SRS-3, Photo Research, USA) [24]. A saturated sucrose solution (refractive index $n=\sim 1.5$ ) was used as a coupling agent $[25,26]$. Color measurements were performed using a constant direct illumination from two optical fibers (70050, Newport Stratford) with color temperature $6500 \mathrm{~K}$ and illuminating/measuring geometry of CIE $45^{\circ} / 0^{\circ}$ [27]. Three short-term repeated measurements without replacement were performed for each specimen, and the results were averaged. Spectral reflectance values were converted into CIE L*a*b* color coordinates using the CIE $2^{\circ}$ standard observer and the CIE D65 standard illuminant [28]. The translucency parameter (TP) was calculated according to the CIELAB-based equation [29]:

$$
\mathrm{TP}=\sqrt{\left(\mathrm{L}_{\mathrm{B}}^{*}-\mathrm{L}_{\mathrm{W}}^{*}\right)^{2}+\left(\mathrm{a}_{\mathrm{B}}^{*}-\mathrm{a}_{\mathrm{w}}^{*}\right)^{2}+\left(\mathrm{b}_{\mathrm{B}}^{*}-\mathrm{b}_{\mathrm{W}}^{*}\right)^{2}}
$$

where the subscripts $\mathrm{B}$ and $\mathrm{W}$ refer to color coordinates over black and white backgrounds, respectively. In addition, the translucency parameter was also calculated using CIEDE2000 color difference metric $\left(\mathrm{TP}_{00}\right)$ [30]: 


$$
\mathrm{TP}_{\mathrm{oo}}=\sqrt{\left(\frac{\mathrm{L}_{\mathrm{B}}^{\prime}-\mathrm{L}_{\mathrm{W}}^{\prime}}{\mathrm{K}_{\mathrm{L}} \cdot \mathrm{S}_{\mathrm{L}}}\right)^{2}+\left(\frac{\mathrm{C}_{\mathrm{B}}^{\prime}-\mathrm{C}_{\mathrm{W}}^{\prime}}{\mathrm{K}_{\mathrm{C}} \cdot \mathrm{S}_{\mathrm{C}}}\right)^{2}+\left(\frac{\mathrm{H}_{\mathrm{B}}^{\prime}-\mathrm{H}_{\mathrm{W}}^{\prime}}{\mathrm{K}_{\mathrm{H}} \cdot \mathrm{S}_{\mathrm{H}}}\right)^{2}+\mathrm{R}_{\mathrm{T}} \cdot\left(\frac{\mathrm{C}_{\mathrm{B}}^{\prime}-\mathrm{C}_{\mathrm{W}}^{\prime}}{\mathrm{K}_{\mathrm{C}} \cdot \mathrm{S}_{\mathrm{C}}}\right)+\left(\frac{\mathrm{H}_{\mathrm{B}}^{\prime}-\mathrm{H}_{\mathrm{W}}^{\prime}}{\mathrm{K}_{\mathrm{H}} \cdot \mathrm{S}_{\mathrm{H}}}\right)}
$$

where the subscripts B and W refer to L' (lightness), C' (chroma), and H' (hue) of the specimens over the black and the white backgrounds, respectively, parametric factors $\mathrm{K}_{\mathrm{i}}$ are correction terms for experimental conditions, weighting functions $\mathrm{S}_{\mathrm{i}}$ adjust the color difference, and $R_{T}$ is the rotation function for the interaction between chroma and hue differences in the blue region [27]. The discontinuities due to mean hue computation and hue difference computation were taken into account, according to the findings from a previous study [31]. Translucency differences $(\Delta \mathrm{TP})$ between both materials were analyzed with translucency perceptibility threshold (TPT $=1.33$ and $\left.\mathrm{TPT}_{00}=0.62\right)$ and translucency acceptability threshold (TAT $=4.43$ and $\mathrm{TAT}_{00}=2.62$ ) [32].

Microstructural analysis: after the translucency evaluation, one specimen of each material was randomly selected to perform a microstructural analysis. The polished surface of both materials was previously acid etched with 5\% hydrofluoric acid for $20 \mathrm{~s}$ and rinsed with water for $60 \mathrm{~s}$ [21]. Specimens were ultrasonic cleaned in a $70 \%$ alcohol bath for $15 \mathrm{~min}$. Then, specimens were sputter-coated with gold-palladium and examined using a scanning electron microscope (SEM, LM, VEGA3, Tescan).

Statistical analysis: the mean and standard deviation values of biaxial flexural strength $\left(\sigma_{\mathrm{f}}\right)$ and translucency parameter (TP and $\mathrm{TP}_{00}$ ) were statistically analyzed using a t-test $(\alpha=0.05)$. Vickers microhardness (HV) and fracture load $\left(\mathrm{L}_{\mathrm{f}}\right)$ data failed the Shapiro-Wilk normality test and equal variance test. Thus, the Mann-Whitney test was used for statistical analysis $(\alpha=0.05)$. Weibull distribution was used to statistically analyze the data (biaxial flexural strength and fracture load) and estimate the Weibull modulus $(\mathrm{m})$. The Weibull analysis was performed using the least-squares method, and tabulated values were used to calculate the $95 \%$ confidence intervals (95\% CI). Statistical differences between the Weibull parameters were found when the $95 \%$ confidence intervals did not overlap. The relationship between failure mode observed in the monotonic compressive load test and the type of restorative material was evaluated with Fischer's test $(\alpha=0.05)$.
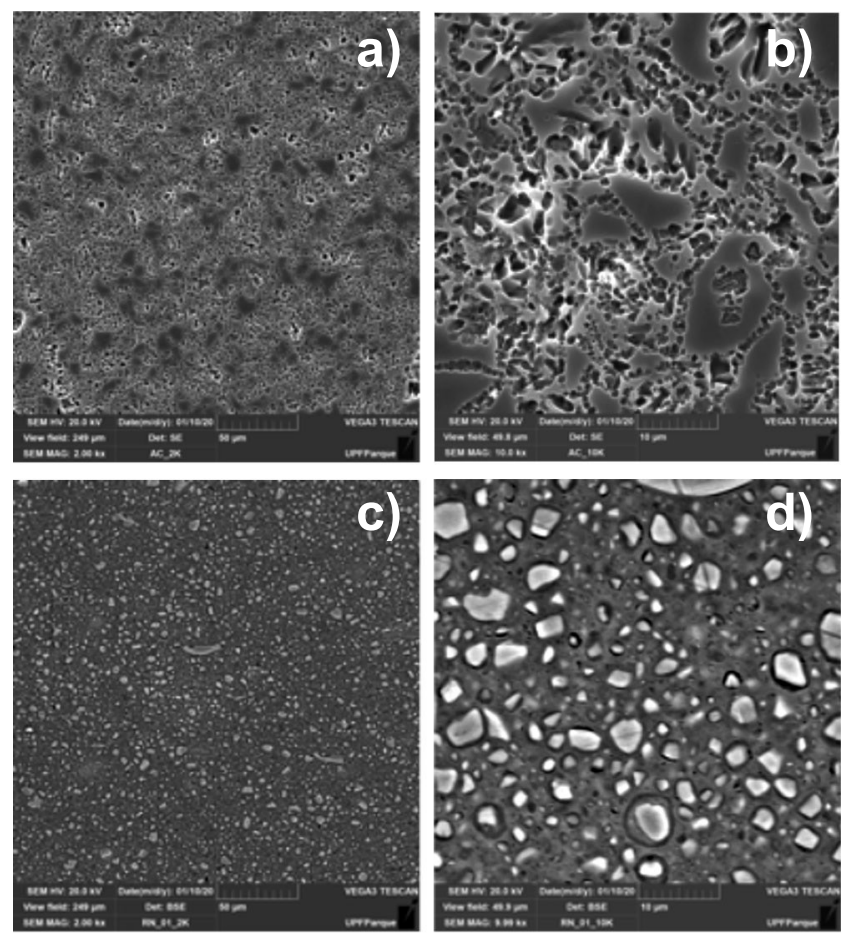

Figure 1: SEM images of polished surfaces of leucite-reinforced glass-ceramic - IE (a,b) and nanoceramic resin - LU (c,d) specimens after etching with $5 \%$ hydrofluoric acid.

[Figura 1: Imagens de MEV de superfícies polidas de espécimes de vitrocerâmica reforçada por leucita IE $(a, b)$ e resina nanocerâmica - LU $(c, d)$ após condicionamento com ácido fluorídrico a 5\%.]

\section{RESULTS}

Fig. 1 presents the microstructure images of IE and LU. For IE, it was possible to observe round cavities homogeneously distributed in the glass matrix that corresponded to the dissolved leucite crystals (Figs. 1a and 1b). For LU, zirconia-silica particle agglomerates were dispersed in the polymeric matrix (Figs. 1c and 1d).

Non-cemented LU specimens showed significantly higher biaxial flexural strength $(\mathrm{P}<0.001)$, characteristic strength $\left(\sigma_{0}\right)$, and Weibull modulus $(\mathrm{m})$ than IE (Table II). IE showed higher values of Vickers microhardness than LU $(\mathrm{P}<0.01$, Table II). When cemented to the substrate, LU had higher fracture load $\left(\mathrm{L}_{\mathrm{f}}\right)$ and characteristic

Table II - Mean and standard deviation values of flexural strength $\left(\sigma_{\mathrm{f}}\right)$, characteristic strength $\left(\sigma_{0}\right)$, and Weibull modulus $(\mathrm{m})$, with their respective confidence intervals $(95 \% \mathrm{CI} ; \mathrm{n}=30)$, and median values of Vickers microhardness $(\mathrm{HV})$ and interquartile range (IQR; $\mathrm{n}=5$ ) for each experimental group.

[Tabela II - Valores de média e desvio-padrão de resistência flexural $\left(\sigma_{f}\right)$, resistência característica $\left(\sigma_{0}\right)$ e módulo de Weibull $(m)$, com seus respectivos intervalos de confiança (95\% CI; $n=30)$, e mediana de microdureza Vickers $(H V)$ e intervalo interquartil (IQR; $n=5)$ para cada grupo experimental.]

\begin{tabular}{cccccccc}
\hline Material & $\sigma_{\mathrm{f}}(\mathrm{MPa})$ & $\sigma_{0}(\mathrm{MPa})$ & $\mathrm{CI}_{95 \%, \mathrm{\sigma o}}(\mathrm{MPa})$ & $\mathrm{m}$ & $\mathrm{CI}_{95 \%, \mathrm{~m}}$ & $\mathrm{HV}$ & $\mathrm{IQR}$ \\
\hline $\mathrm{LU}$ & $201 \pm 22^{\mathrm{a}}$ & $211^{\mathrm{a}}$ & $204-218$ & $10^{\mathrm{a}}$ & $7.5-12.2$ & $115^{\mathrm{b}}$ & 18 \\
$\mathrm{IE}$ & $96 \pm 18^{\mathrm{b}}$ & $103^{\mathrm{b}}$ & $97-109$ & $6^{\mathrm{b}}$ & $4.5-7.3$ & $826^{\mathrm{a}}$ & 66 \\
\hline
\end{tabular}

Note: values followed by the same letter in the same column are statistically similar $(P>0.05)$. 
Table III - Median values of fracture load $\left(\mathrm{L}_{\mathrm{f}}\right)$ and interquartile range (IQR), characteristic fracture load $\left(\mathrm{L}_{0}\right)$, Weibull modulus $(\mathrm{m})$, with their respective confidence intervals $(95 \% \mathrm{CI})$, and frequency of each failure mode for the experimental groups. [Tabela III - Valores medianos de carga de fratura $\left(L_{f}\right)$ e intervalo interquartil (IQR), carga de fratura característica $\left(L_{0}\right)$, módulo de Weibull $(\mathrm{m})$, com seus respectivos intervalos de confiança $(95 \% \mathrm{CI})$, e frequência de cada modo de falha para cada grupo experimental.]

Fracture load*

Failure mode**

\begin{tabular}{ccccccccc}
\multirow{2}{*}{ Material } & \multicolumn{9}{c}{ Fracture load* } & \multicolumn{3}{c}{ Failure mode** } \\
& $\mathrm{L}_{\mathrm{f}}(\mathrm{N})$ & $\mathrm{IQR}$ & $\mathrm{L}_{0}(\mathrm{~N})$ & $\mathrm{CI}_{95 \%, \mathrm{Lo}}(\mathrm{N})$ & $\mathrm{m}$ & $\mathrm{CI}_{95 \%, \mathrm{~m}}$ & Radial crack & Cone crack \\
\hline $\mathrm{LU}$ & $5530^{\mathrm{a}}$ & 530 & $5893^{\mathrm{a}}$ & $5591-6217$ & $8^{\mathrm{a}}$ & $5.5-10.1$ & 0 & 20 \\
$\mathrm{IE}$ & $825^{\mathrm{b}}$ & 287 & $957^{\mathrm{b}}$ & $892-1028$ & $6^{\mathrm{a}}$ & $4.1-7.6$ & 20 & 0 \\
\hline
\end{tabular}

* values followed by the same letter in the same column are statistically similar $(P>0.05)$; ** Fischer test $(P<0.001)$.
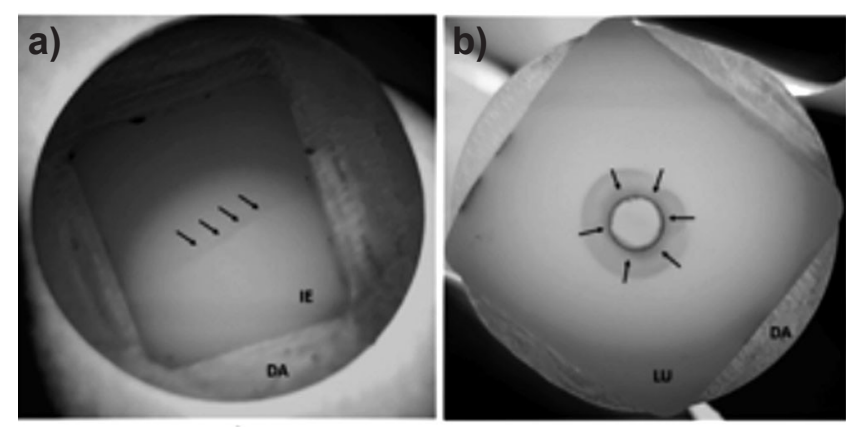

Figure 2: Images of the fracture surfaces of specimens tested in compression: a) black arrows point to a radial crack located in the intaglio surface of IE specimen cemented over the dentin analog (DA); and b) black arrows point to a cone crack in the surface of LU specimen.

[Figura 2: Imagens de superfícies de fratura de corpos de prova testados em compressão: a) setas pretas apontam para a trinca radial localizada na superfície inferior da IE, na interface de cimentação com o substrato análogo à dentina (DA); e b) setas pretas apontam para a trinca do tipo cone na superficie da LU.]

fracture load $\left(\mathrm{L}_{0}\right)$ than IE $(\mathrm{P}<0.001)$. Yet, cemented LU and IE specimens showed similar $m$ values, as the $95 \%$ confidence intervals overlapped (Table III). The frequency of each failure mode for the cemented specimens is also presented in Table III. There was a significant relationship between the failure mode and the type of restorative material $(\mathrm{P}<0.001)$. Radial cracks were found for IE and cone cracks for LU (Fig. 2). Considering the translucency parameter, the restorative materials LU $\left(\mathrm{TP}=21.19 \pm 0.17 ; \mathrm{TP}_{00}=14.59 \pm 0.11\right)$ and $\mathrm{IE}$ $\left(\mathrm{TP}=19.87 \pm 0.15 ; \mathrm{TP}_{00}=13.46 \pm 0.09\right)$ showed statistical differences $(\mathrm{P}<0.001)$. $\Delta \mathrm{TP}$ between both materials was 1.32 units for $\mathrm{TP}$ (below the TPT) and 1.13 units for $\mathrm{TP}_{00}$ (above $\mathrm{TPT}_{00}$ but below $\mathrm{TAT}_{00}$ ).

\section{DISCUSSION}

The present study investigated the mechanical behavior of cemented and non-cemented restorative materials aiming to simulate the multilayer configuration and stress distribution observed in the occlusal area of adhesively bonded indirect restorations, when loaded in compression by the antagonist cusp. Cementation influenced the mechanical behavior and failure mode of the nanoceramic resin evaluated, accepting our study hypothesis.

LU showed superior mechanical behavior than IE, regardless of the specimen configuration (cemented vs. noncemented) and testing condition (biaxial flexural strength test vs. monotonic compressive load test). The incorporation of a large amount of inorganic filler in a matrix of UDMA, with a high-performance industrial polymerization process, results in a material with good mechanical properties, as observed in previous studies $[2,8,33]$. The literature reports that LU has lower elastic modulus than IE and superior Poisson's ratio $[21,33]$, meaning that this material undergoes more plastic deformation before fracture. The presence of a continuous phase (organic matrix) and a homogeneous distribution of the inorganic filler particles in LU, as seen in Figs. 1c and 1d, provide a more resilient material and improve its mechanical behavior. Moreover, result in a material with lower microhardness, as shown in this study and previous investigations [2, 7, 8]. A softer restorative material, such as LU, may be desirable to avoid wear of the antagonist tooth but may also be more susceptible to volumetric loss during clinical use [2, 6]. However, LU showed higher reliability $(m=10)$ than IE $(m=6)$ when noncemented specimens were tested, but m-values were similar among materials for cemented specimens ( $\mathrm{LU}=8$ and $\mathrm{IE}=6$ ). Higher Weibull modulus values indicate greater structural reliability, meaning smaller variability in strength estimation and a more uniform flaw distribution, which suggests a more homogeneous microstructure [33-35]. Several factors influence the $\mathrm{m}$-value, such as the specimen fabrication processes and surface treatments, the stress distribution during loading, and the testing environment [33-35]. When non-cemented specimens are tested in biaxial flexural strength, the highest tensile stress concentration is located in the lower surface of the specimen, below the loading region, where the crack origin is usually found [9]. For this testing condition (biaxial flexural strength + polished specimens), LU showed a higher m-value than IE.

However, when multilayered structures are evaluated, the stress distribution is affected by the individual properties of each material (i.e., elastic modulus, flexural strength) and thickness of each layer $[9-13,17,18]$. In the present study, cemented specimens were constituted by a restorative material ( $1.5 \mathrm{~mm}$ thick) cemented with resin cement $(\sim 0.04$ 
$\mathrm{mm}$ thick) to a dentin analog supporting substrate in order to mimic the configuration of an indirect restoration adhesively bonded to a tooth [9-13]. For a multilayered specimen of the leucite-reinforced glass-ceramic, which is a stiff material $(\mathrm{E}=65 \mathrm{GPa})$, compressive loading led to the concentration of tensile stresses in the cementation surface of the IE. This stress distribution was related to the deflection of the resilient substrate during loading and the mismatch between the elastic properties of the materials (G10, E=15 GPa) [13]. Radial cracks can originate and propagate from the lower surface of the ceramic [9-11], similar to the failure behavior observed for non-cemented specimens tested in biaxial flexural strength. Therefore, for IE, the stress distribution and failure mode were similar in both testing conditions. On the contrary, when the elastic and mechanical properties of the distinct materials are similar, as observed for the nanoceramic resin multilayered specimens, a more uniform stress distribution is induced during compressive loading, which favors its mechanical behavior. Tensile stresses at the restorative material lower surface are suppressed, leading to failures originated in the top surface, in the region in contact with the loading piston, called cone cracks $[12,13]$. In this case, the absence of radial cracks and debonding during testing may also suggest a good adhesion between the LU restorative material, the resin cement, and the substrate.

Adhesive cementation requires the material's surface to be treated, aiming to increase the surface area and to promote micromechanical and chemical bond to the substrate [36]. Etching the surface with hydrofluoric acid prior to adhesive cementation is recommended for acid-sensitive glassceramics, such as IE [36]. Otherwise, air-particle abrasion is recommended for $\mathrm{LU}$ as acid-etching fails to improve its bond strength to the resin cement [37]. Therefore, different surface treatments were used to cement the specimens, which could affect the surface flaw population and reliability. Nevertheless, the interaction of the resin cement with the surface defect population can create a resin-ceramic hybrid layer that enhances the structure fracture strength [19]. In addition, studies showed that the strengthening mechanisms were not dependent on the surface flaw population [16-18]. In the present study, these strengthening mechanisms of resin cement on the ceramic surface could improve the mechanical behavior of IE cemented specimens. Yet, for cemented LU, failure did not originate from the treated cementation surface but from the top surface in contact with the piston. Clinically, indirect resin composite inlays and onlays show mechanical failures due to occlusal cohesive fractures that can involve the cusps and/or the marginal ridges [38]. These failures can be associated to contact damages like the ones observed in the present study. Moreover, a fractographic study of clinically fractured, implant-supported, LU crowns indicated that the failure origin was located either in the cusp, where a large wear facet and damage accumulation zone was observed, or in the intaglio surface, especially in the margins [39]. Different from the present study, in this clinical investigation, LU crowns were cemented over much stiffer zirconia implant abutments. For monolithic glass-ceramic restorations, catastrophic clinical failures are usually associated with radial cracks, as the ones seen for IE cemented specimens, that initiated in the prosthesis intaglio surface or in the margins. Contact damages are mainly related to small fractures, such as chipping, and usually can be repaired [13].

To guarantee the success of the prosthetic treatment, it is also important to understand the optical properties of the restorative materials. The translucency has been considered one of the main controlling factors of the aesthetic result of the restorations, making them appear more natural [3]. The scattering and the passage of light through the material is representative of the translucency, and can be described as the state between total transparency and total opacity [7]. Both materials presented high translucency, although LU showed higher TP values than IE, which was in agreement with previous findings [7]. LU contains nanoparticles of an inorganic filler with a diameter lower than the wavelength of visible light, which causes less dispersion and absorption of light. Nevertheless, when the translucency thresholds are used to compare both materials, the value of $\Delta \mathrm{TP}(1.32$ units) was below the translucency perceptibility threshold (TPT=1.33), and the value of $\Delta \mathrm{TP}_{00}(1.13$ units $)$ was above the translucency perceptibility threshold $\left(\mathrm{TPT}_{00}=0.62\right)$ but below the translucency acceptability threshold $\left(\mathrm{TAT}_{00}=2.62\right)$. As CIEDE2000 offers a better data fit than CIELAB metric for translucency thresholds [32], it can be assumed that both materials show acceptable translucency differences for common human observers.

This in vitro study followed all the cementation steps recommended by the manufacturer of the materials in order to mimic the clinical conditions. The supporting substrate material had similar elastic and adhesive behavior to hydrated dentin [9, 12]. Additionally, the load was applied by a ceramic piston, as this material could induce the same stress distribution to the specimens as the human tooth [10]. The compressive monotonic load test was designed to register the load associated with the beginning of the failure process. Yet, it was more difficult to identify the sound of the initial crack for LU, probably due to its viscoelastic nature. Thus, the fracture load values for LU specimens may be overestimated, which is a study limitation, although, no catastrophic failure was observed. Moreover, it is known that the organic matrix of composites is susceptible to degradation in an aqueous environment, which could compromise its mechanical and optical properties [5]. Therefore, fatigue and aging tests are recommended to further characterize its long-term behavior $[9,11,12]$. Yet, a higher degree of monomeric conversion is expected for these CAD/CAM pre-polymerized composite materials, improving its chemical and physical stability [6].

\section{CONCLUSIONS}

Cementation influenced the mechanical behavior and failure mode of the nanoceramic resin. Nanoceramic resin cemented specimen had similar reliability than leucitereinforced glass-ceramic, but different failure mode. The 
nanoceramic resin showed mechanical and optical properties that favor its clinical behavior.

\section{ACKNOWLEDGMENT}

The authors do not have any financial interest in the companies whose materials are included in this article. This work was partially supported by "Junta de Andalucía" (Spain, grant number JA TEP-1136).

\section{REFERENCES}

[1] A. Della Bona, P.H. Corazza, Y. Zhang, Dent. Mater. 30 (2014) 564.

[2] W.H. Mörmann, B. Stawarczyk, A. Ender, B. Sener, T. Attin, A. Mehl, J. Mech. Behav. Biomed. Mater. 20 (2013) 113.

[3] A.D. Nogueira, A. Della Bona, J. Dent. 41 (2013) e18.

[4] O. Acar, B. Yilmaz, S.H. Altintas, I. Chandrasekaran, W.M. Johnston, J. Prosthet. Dent. 115 (2016) 71.

[5] S.H. Lee, Y.K. Lee, B.S. Lim, J. Mater. Sci. Mater. Med. 15 (2004) 1221.

[6] A.K. Mainjot, N.M. Dupont, J.C. Oudkerk, T.Y. Dewael, M.J. Sadoun, J. Dent. Res. 95 (2016) 487.

[7] A. Albero, A. Pascual, I. Camps, M. Grau-Benitez, J. Clin. Exp. Dent. 7 (2015) e495.

[8] N. Sonmez, P. Gultekin, V. Turp, G. Akgungor, D. Sen, E. Mijiritsky, BMC Oral Health 18 (2018) 5.

[9] Y.J. Yi, J.R. Kelly, Dent. Mater. 27 (2011) 1252.

[10] K.R. Weber, P. Benetti, A. Della Bona, P.H. Corazza, J.A. Medeiros, E. Lodi, M. Borba, J. Prosthet. Dent. 120 (2018) 747.

[11] E. Lodi, K.R. Weber, P. Benetti, P.H. Corazza, A. Della Bona, M. Borba, J. Prosthet. Dent. 119 (2018) 812.

[12] J.C. Facenda, M. Borba, P. Benetti, A. Della Bona, P.H. Corazza, J. Prosthet. Dent. 121 (2019) 929.

[13] B.R. Lawn, A. Pajares, Y. Zhang, Y. Deng, M.A. Polack, I.K. Lloyd, E.D. Rekow, V.P. Thompson, Biomaterials 25 (2004) 2885.

[14] K.A. Malament, S.S. Socransky, J. Prosthet. Dent. 81 (1999) 23.

[15] K.A. Malament, S.S. Socransky, J. Prosthet. Dent. 81 (1999) 662.

[16] G.J. Fleming, F.R. Maguire, G. Bhamra, F.M. Burke, P.M. Marquis, J. Dent. Res. 85 (2006) 272.

[17] O. Addison, P.M. Marquis, G.J. Fleming, J. Dent. Res. 6 (2007) 519.

[18] O. Addison, P.M. Marquis, G.J. Fleming, J. Dent. Res.
6 (2008) 542.

[19] X. Cao, G.J.P. Fleming, O. Addison, Dent. Mater. 5 (2017) 498.

[20] ISO 6872, "Dentistry: ceramic materials", $4^{\text {th }}$ ed., Int. Org. Stand., Geneva (2015).

[21] R. Belli, M. Wendler, D. de Ligny, M.R. Cicconi, A. Petschelt, H. Peterlik, U. Lohbauer, Dent. Mater. 33 (2017) 84.

[22] N. Ilie, T.J. Hilton, S.D. Heintze, R. Hickel, D.C. Watts, N. Silikas, J.W. Stansbury, M. Cadenaro, J.L. Ferracane, Dent. Mater. 33 (2017) 880.

[23] ISO 14705, "Fine ceramics (advanced ceramics, advanced technical ceramics), test method for hardness of monolithic ceramics at room temperature", $3^{\text {rd }}$ ed., Int. Org. Stand., Geneva (2016).

[24] M.M. Basegio, O.E. Pecho, R. Ghinea, M.M. Perez, A. Della Bona, Dent. Mater. 35 (2019) e122.

[25] O.E. Pecho, R. Ghinea, E.A. do Amaral, J.C. Cardona, A. Della Bona, M.M. Pérez, Dent. Mater. 32 (2016) e105.

[26] M.M. Perez, C. Hita-Iglesias, R. Ghinea, A. Yebra, O.E. Pecho, A.M. Ionescu, A. Crespo, E. Hita, Dent. Mater. J. 35 (2016) 353.

[27] Commis. Int. l'Eclairage, Techn. Rep. Colorimetry, Pub. 15.3, CIE Central Bureau, Vienna (2004).

[28] ISO/TR28642, "Dentistry, guidance on colour measurement”, Int. Org. Stand., Geneva (2016).

[29] W.M. Johnston, T. Ma, B.H. Kienle, Int. J. Prosthodont. 8 (1995) 79.

[30] D. Kürklü, S.S. Azer, B. Yilmaz, W.M. Johnston, J. Dent. 41 (2013) 1043.

[31] G. Sharma, W. Wu, E.N. Dalal, Color Res. Appl. 30 (2005) 21.

[32] M. Salas, C. Lucena, L.J. Herrera, A. Yebra, A. Della Bona, M.M. Pérez, Dent. Mater. 34 (2018) 1168.

[33] B.J. Choi, S. Yoon, Y.W. Im, J.H. Lee, H.J. Jung, H.H. Lee, Dent. Mater. 35 (2019) 389.

[34] A. Della Bona, K.J. Anusavice, P.H. DeHoff, Dent. Mater. 19 (2003) 662.

[35] A.C. Piccoli, M. Borba, Cerâmica 64, 370 (2018) 284.

[36] A. Della Bona, M. Borba, P. Benetti, O.E. Pecho, R. Alessandretti, J.C. Mosele, R.T. Mores, Curr. Oral Health Rep. 1 (2014) 232.

[37] J. Park, Y. Choi, J. Adv. Prosthodont. 8 (2016) 275.

[38] F. Angeletaki, A. Gkogkos, E. Papazoglou, D. Kloukos, J. Dent. 53 (2016) 12.

[39] U. Lohbauer, R. Belli, M.S. Cune, U. Schepke, SAGE Open Med. Case Rep. 5 (2017) 1.

(Rec. 12/11/2019, Rev. 22/01/2020, Ac. 07/02/2020) 